\title{
Pathways to climate-neutral shipping: A Danish case study
}

\author{
ben Brahim, Till Sebastian; Wiese, Frauke; Münster, Marie
}

\section{Published in:}

\section{Energy}

Link to article, DOI:

10.1016/j.energy.2019.116009

Publication date:

2019

Document Version

Peer reviewed version

Link back to DTU Orbit

Citation (APA):

ben Brahim, T. S., Wiese, F., \& Münster, M. (2019). Pathways to climate-neutral shipping: A Danish case study. Energy, 188, [116009]. https://doi.org/10.1016/j.energy.2019.116009

\section{General rights}

Copyright and moral rights for the publications made accessible in the public portal are retained by the authors and/or other copyright owners and it is a condition of accessing publications that users recognise and abide by the legal requirements associated with these rights.

- Users may download and print one copy of any publication from the public portal for the purpose of private study or research.

- You may not further distribute the material or use it for any profit-making activity or commercial gain

- You may freely distribute the URL identifying the publication in the public portal

If you believe that this document breaches copyright please contact us providing details, and we will remove access to the work immediately and investigate your claim 


\title{
Pathways to Climate Neutral Shipping - A Danish Case Study
}

\author{
Till ben Brahim ${ }^{\mathrm{a}, *}$, Frauke Wiese ${ }^{\mathrm{a}}$, Marie Münster ${ }^{\mathrm{a}}$ \\ ${ }^{a}$ Technical University of Denmark, Produktionstorvet 426, 2800 Kongens Lyngby, Denmark
}

\begin{abstract}
In this paper, we describe pathways for the Danish maritime cargo sector to $\mathrm{CO}_{2} \mathrm{e}$ (equivalent) neutrality in 2050 in compliance with the Paris Agreement. In our model approach, we not only include national greenhouse gas emissions, but also suggest a method to assign greenhouse gas emissions from international shipping to countries. Our modelling results indicate, that either strong regulative carbon budgets or a carbon price of $350-450 €_{2016} / \mathrm{t} \mathrm{CO}_{2} \mathrm{e}$ would be necessary to induce the urgent transition. This would double today's average cargo transport costs, but increase average import values only by $6-8 \%$. Regarding fuel technologies, hydrogen, methanol and ammonia are most compatible from a socio-economic cost perspective. Though, due to high cost uncertainties, there is no clear winner. Liquefied natural gas as an alternative intermediate solution would only have a short window of opportunity, due to methane leakage causing high greenhouse gas emissions as well as high fuel and technology costs. If this gaseous fuel is based on renewable sources it can play a role, but only in case of drastically reduced methane leakage.
\end{abstract}

Keywords: Maritime transport, Marine fuels, Energy modelling, Emission reduction, International cargo, Shipping emissions

\section{Introduction}

The ambition to reach climate pathways with limited overshoot of $1.5{ }^{\circ} \mathrm{C}$ requires global net zero $\mathrm{CO}_{2} \mathrm{e}$ emissions by 2050 [1]. This implies a massive reduction of fossil fuels in the energy system. Several studies based on energy system models have shown possible pathways to net zero emissions for the electricity supply from country to continents and the whole world [2] and also for the heat sector. Although transport is more challenging [3, 4, in recent years an increasing amount of studies also includes pathways for this sector to net zero emissions in 2050. However, the majority of scenarios leaves out a significant

\footnotetext{
* Corresponding author

Email address: tilseb@dtu.dk (Till ben Brahim)
} 
part of the transport emissions, namely international shipping. Due to its international nature, appropriate governance is challenging [5]. So far, countries leave out international shipping in their energy and climate plans, leaving the responsibility to the International Maritime Organisation (IMO). While - to some extent - progress has been made regarding sulphur emission reduction, their goal of $50 \%$ greenhouse gas reduction until 2050 of worldwide shipping [6] is neither ambitious enough to reach the goals of the Paris Agreement, nor underpinned with measures and possible pathway descriptions [7].

While liquefied natural gas (LNG) has mainly been in the focus as an conventional alternative marine fuel [8, 9] due to its advantage regarding sulphur oxide $\left(\mathrm{SO}_{X}\right)$, nitrogen oxide $\left(\mathrm{NO}_{X}\right)$ and particle emissions $(\mathrm{PM})$, its possibility to also reduce climate impact of shipping has increasingly been questioned [10. This is on the one hand due to its limited $\mathrm{CO}_{2}$ emission benefit compared to oil [11. On the other hand, the implications for greenhouse gases (GHG) depend on how the natural gas is extracted, processed, distributed, and used [12]. According to the International Energy Agency, the average global gas methane leakage rate is $1.7 \%$ for natural gas [13, while a recent assessment of methane emissions from the U.S. oil and gas supply chain conclude 2.3\% [14]. Looking at a global warming potential over a 20-year time frame, a leakage rate of 3$4 \%$ would already use up the climate benefit of natural gas compared to coal, over a 100-year time frame it is 6-7 \%. Hagos and Ahlgren [15] state that a $1 \%$ methane slip from a dedicated LNG passenger vessel results, on average, in 8.5\% increase in net GHG emissions. According to measurements and calculations based on [16, 17, methane slip of dual-fuel engines amounted to roughly $4 \%$ and dedicated gas engines to $2.3 \%$ in 2016. Although LNG-specialised engines with high pressure direct injection could lower leakage rates even further, ship owners today prefer dual-fuel engines as they judge flexibility and the resale value of the ship more important than efficiency gains because climate impact is not reflected in any economic value for shipping. In summary, the climate impact of both, LNG and methanol produced from natural gas is assessed to have the same order of magnitude as heavy fuel oil [18, 19].

Independent of the role of LNG, one can generally conclude, that the current concentration on reduction of $\mathrm{SO}_{X}, \mathrm{NO}_{X}$ and PM in shipping is too shortsighted [20, since climate emissions from shipping are the bigger challenge [21]. More radical changes avoiding infrastructure lock-ins and exploring co-benefits of sulphur and carbon reduction are advisable. In line with that, the discussion about climate and other emission compatible future marine fuels has gained momentum in recent years. Indirect electrification via hydrogen or other synthetic fuels could be a promising option 22. Their potential can be significant if relying on de-carbonised inputs while the potential of bio-derived fuels are strongly related to their respective scarcity [20. Also wind-energy in form of soft-sails, fixed-sails, Flettner Rotors or kite sails are options being tested [23.

Another important aspect of reducing emissions additionally to fuel switch is energy efficiency, whose potential has not been completely exploited yet 24, 25] and could be further improved applying e.g. waste heat recovery to a greater extent [26]. Furthermore, operational measures like slow steaming [27], hull 
design and larger vessels [28] can provide significant contributions to lowering emissions in shipping. However, as Olmer et al. 29] show, shipping will need to move beyond energy efficiency interventions alone to achieve absolute emission reductions.

Calculating different pathways until 2050, a study from Lloyd's Register 30] comes to the conclusion, that different options are possible, mostly depending on the availability of biomass, the development of transport demand and technology learning, but independent of the pathway, all require a substitute for fossil fuel since operational measures are not sufficient. A meta-study looking at measures and fuels of various studies [31] suggests that a $75 \%$ emission reduction is possible until 2050, but only with a combination of various measures. Looking at possible reduction targets, Smith et al. 32 describe the pathway to zero emissions in 2035 in their most ambitious scenario. An initiative from the shipping industry itself is striving for zero emission vessels [33, also worked on by Lloyd's Register [34. Additionally to studies taking the general and national perspective, there is ongoing research about specific applications, like e.g. batteries in offshore support vessels [35], specific fuel options, like e.g. slow steaming and wind propulsion [36 or specific areas like emission reduction in port [37.

Looking at the regulative side, Shi 38] suggests a scheme of market-based measures that can be adopted by means of an international convention under the auspices of the International Maritime Organisation (IMO) and the UNFCCC. This could be a global emission trading scheme including shipping and aviation [39], while Gritsenko [5] suggests polycentric governance. Although the technical, economical and regulative options for shipping to take its share in the climate responsibility have risen, regarding its importance and urgency, it is still under-represented in current discussions and studies assessing energy transformation. Its importance is due to (1) the general efficiency of shipping compared to other means of transport, (2) its large share in worldwide transported goods and (3) the wide range of GHG emission predictions. According to the upper bound of predictions, future maritime transport emissions would increase by $250 \%$ in 2050 40. However, other predictions actually assume a decrease in transport demand due to less fossil fuel transported, as well as increased circular economy and effects from 3D-printing [41.

The urgency is due to mainly three reasons: (1) Very long investment cycles of ships. This leads to the situation, that decisions about the fuels to reach net zero emissions in 2050 are just around the corner. (2) Infrastructure requirements being essential and requiring long planning horizons and (3) the increasing interdependence between fuels applied in shipping and our land-based energy systems (electricity, heat, fuels for transport). Developments in shipping fuels will affect decisions on energy infrastructure on land and vice versa. Examples are future refineries providing fuels for shipping and land-based heavy transport, producing excess heat during the fuel production. Thus, options have to be intensively looked at and also optimised in combination with the rest of the energy system.

This paper contributes to fill the research gap between studies on inland 
shipping with a high level of detail but limited scope on the one side and international shipping in low resolution regarding technology and fuels on the other side. Our modelling approach takes emissions from international shipping into account but can still be applied to single or several countries. It could thus be integrated in national energy and climate modelling scopes. Although we exemplary model Danish shipping, the methodology can be applied to other countries as well. Unlike most other studies, data and model not only include costs for fuels and technologies but also infrastructure costs. Emission-wise, the whole picture is covered by taking well-to-propeller climate emissions including methane leakage into account while complying with current and future $\mathrm{SO}_{X}$ and $\mathrm{NO}_{X}$ emission restrictions. In this holistic approach, today's and possible future fuels and technologies are evaluated by an optimisation model, minimising total system costs while reaching net zero GHG emissions in 2050. Due to high uncertainty regarding cost development, we perform a threshold analysis providing an overview of fuel-technology combinations likely to play a role in the future.

In section 2, we describe the model scope (subsection 2.1), structure subsection 2.2), the mathematical formulation subsection 2.3), data sources and processing (subsection 2.4 and explain our scenario approach subsection 2.5). The underlying data collection, model and scenario development is based on and further described in 42 . Subsequently, we present the scenario and threshold analysis results and discuss their relevance, also describing strengths and weaknesses of the model approach (section 3) and finally draw conclusions section 4.

\section{Materials and Methods}

\subsection{Model Scope}

The framework developed for this study minimises total system costs in compliance with constraints like emission restrictions. It can be applied to illustrate potential pathways of maritime transport in annual resolution. Costs include fuel, ship and infrastructure costs and are seen from a socio-economic perspective, excluding externalities. Since it is combined with a stock model of existing ships and infrastructure, components at the end of their lifetime are replaced by new endogenous model investments. At its current status, the model framework distinguishes ship-technology combinations by their main engine and fuel type. Operational patterns like varying speed or ship design like hull-shapes are not considered. Regarding emissions, $\mathrm{SO}_{X}, \mathrm{NO}_{X}, \mathrm{CO}_{2}$ and methane $\left(\mathrm{CH}_{4}\right)$ limitations can be set.

In our model application, the temporal scope is chosen until 2050 since this is the target year for reaching net zero emissions in compliance with the Paris Agreement. To be able to include Danish national and international cargo, we developed an approach for distributing international shipping to countries as illustrated in Figure 1. The route and thus fuel usage and associated emissions

of each trip from or to a Danish port and half of the international trips are 
assigned to Danish shipping. Regarding $\mathrm{SO}_{X}$ and $\mathrm{NO}_{X}$ emissions, regional and global legal restrictions defined in Marpol Annex VI regulations 13 and 14 [43, 44] are applied. GHG emissions are summarised as $\mathrm{CO}_{2} \mathrm{e}$, including $\mathrm{CO}_{2}$ and $\mathrm{CH}_{4}$. Inline with the IPCC [45, we assume that the radiative forcing over a 100-year time horizon for $\mathrm{CH}_{4}$ compared to $\mathrm{CO}_{2}$ is 25 times higher. This can be seen as the lower bound for global warming potential of $\mathrm{CH}_{4}$ since this factor has been increased in more recent reports.

The overall remaining GHG emission budget is derived from the IPCC's RCP2.6 scenario [46, p. 27], which is further explained in subsubsection 2.4.3. Table B.4 illustrates the combination of technologies and fuels that are available in our model application striving for GHG emission free Danish shipping in 2050.

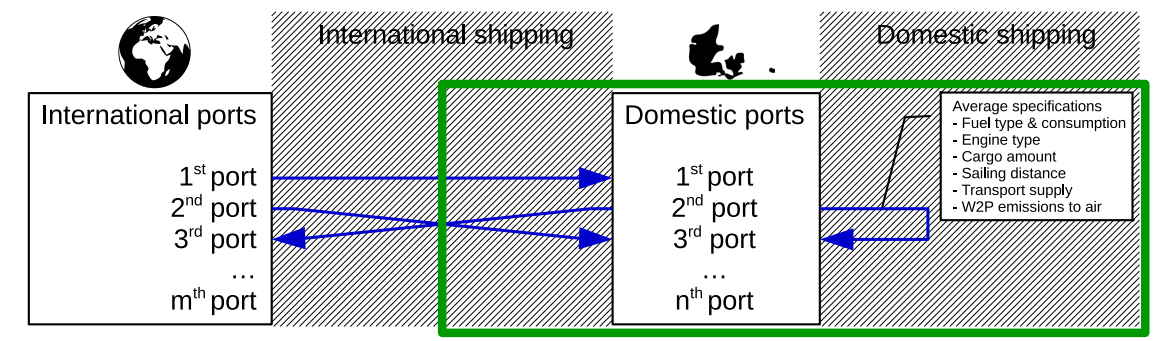

Figure 1: Model boundary: The model considers the specifications inside the green box. Figure taken from 42

\subsection{Model Structure}

While the core components of the model are the equations describing the objective equation and constraints of the optimisation, pre-processing of the input and post-processing of the output data also constitute an important part of the modelling framework. Figure 2 illustrates the model flow with white boxes representing data instances and blue arrows representing processes. These scripts are written in Python with the pre-processing applying the data package panda, the optimisation utilising the optimisation package pyomo and the output processing additionally to pandas mathplotlib for illustrating the results in plots. All scripts, raw and processed data including documentation are available on GitHub [47, where further development of the model takes place. To allow for barrier-free reproducibilty of the presented results, the entire deployed software is open-source and the version of data and code deployed for this research is available at [48. Both are published under the GNU general public license version 3 .

\subsection{Mathematical Formulation}

The problem is formulated in a linear, non-integer manner, aiming to minimise the objective equation. Model variables in the first time step are initialised 


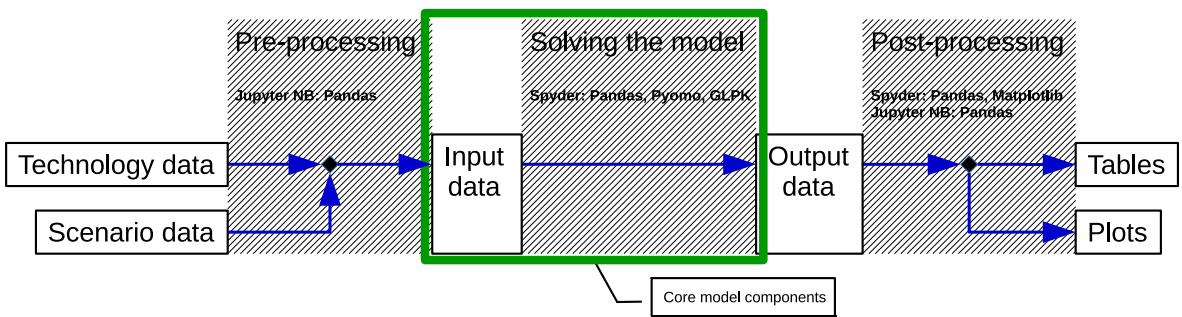

Figure 2: Model boxflow: The core model consists of the components inside the green box. (NB: Notebook; GLPK: GNU Linear Programming Kit)

with data compiled for the current shipping fleet. For the following time steps, different constraints trigger the necessary investment decisions for new technologies and lead to decommissioning of existing ships that are not in compliance with legal obligations or emission targets. Since the objective is to minimise total system costs (Equation 1a), investments are interpreted as conflicting, yet inevitable actions to cope with the constraints, such as lowering emissions to air Appendix A.0.5 and supplying the transport demand in each time step Appendix A.0.4). All model variable domains are within non-negative real numbers, including zero $\left(R_{0}^{+}\right)$. The nomenclature of sets, variables and parameters used in the equations can be found in the nomenclature list Appendix A.0.1). Below, subsubsection 2.3.1 illustrates exemplarily the formulation of the objective equation. The entire mathematical formulation is described in Appendix A.

\subsubsection{Objective equation}

The objective equation (obj. eq.) minimises total system expenditures over all time steps and ship types (aggregated by main engine and fuel). It comprises the sum of costs for fuel consumption, additional infrastructure as well as ship capacity for all years (35 time steps in the described application). Costs for fixed assets - fuel infrastructure (CI) and ships (CS) - are given as annuities and account only with the annual added capacities. The value of the existing amount in the start year $\left(\right.$ finit $_{t, s}$ in $T_{0}$ ) is not included in $C I$ and $C S$.

$$
\min . \sum_{\forall t \in T} \sum_{\forall s \in S}\left(C F_{t, s}+C I_{t, s}+C S_{t, s}\right)
$$


subject to (s.t.)

$$
\begin{aligned}
& C F_{t, s} \geq f_{t, s} \cdot c f_{t, s} \\
& \left.C I_{t, s} \geq \text { iup }_{t, s}-\text { finit }_{t, s}\right) \cdot l i_{s} \cdot c i_{t, s}, \forall t \in T_{0} \\
& C I_{t, s} \geq \operatorname{iup}_{t, s} \cdot l i_{s} \cdot c i_{t, s}, \forall t \in T_{>0} \\
& C S_{t, s} \geq\left(\sup _{t, s}-\text { finit }_{t, s}\right) \cdot l s_{s} \cdot c s_{t, s}, \forall t \in T_{0} \\
& C S_{t, s} \geq \sup _{t, s} \cdot l s_{s} \cdot c s_{t, s}, \forall t \in T_{>0}
\end{aligned}
$$

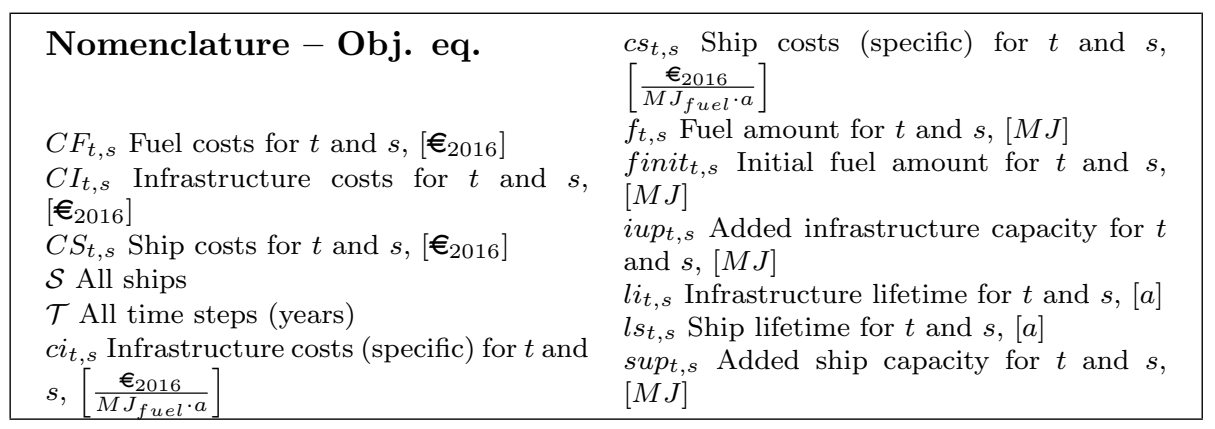

\subsection{Data}

Main input data for the model are fuel and ship type specifications for the initial set of the start year as well as future options for ship-technology combinations. For fuel data, the unique identifier is the fuel type, for ship data it is the ship type. Ship types can use the same fuel, but different engine types like internal combustion (IC), fuel cell (FC), electric motor (EM).

\subsubsection{Fuel data}

The fuel parameters (Table B.3 include $\mathrm{CO}_{2}$ and $\mathrm{CH}_{4}$ emission factors from well-to-tank (w2t), sulphur content as well as cost parameters. Costs are specified for fuel and infrastructure and along with that, the respective lifetime. For fuels that are currently applied on a large scale - heavy fuel oil (HFO), marine diesel oil (MDO), bio-diesel oil (BDO) - the bunker index prices are used. It is assumed that these include all cost components from well to tank including fixed costs for a sufficient supply infrastructure. Thus, for these, infrastructure and fuel costs are not further specified. In contrast, new fuel technology costs are divided into fixed and variable components, since sufficient supply infrastructure has not been installed yet. If fuel upgrading is required, it is assumed to be done at berth to avoid additional grid investments. In the case of Denmark, the gas grid could handle any conceivable amount of natural gas and transport of upgraded biogas. 


\subsubsection{Ship and technology data}

Ship type input parameters (Table B.4 include emission factors, compliance with sulphur and $\mathrm{NO}_{x}$ regulation, lifetime, options for refit, costs, transport supply as well as application options regarding range. The amounts of fuels used today are additionally provided in the tables since these are applied as the starting point in the modelling, while future amounts are determined endogenously by the model.

The emission factors for $\mathrm{CO}_{2}$ and $\mathrm{CH}_{4}$ only include the tank-to-propeller emissions, since the upstream emissions are already covered by the fuel parameters. Regarding sulphur and $\mathrm{NO}_{x}$ compliance, Tier rating defines if a ship complies with IMO $\mathrm{NO}_{x}$ regulations and can thus be operated in a NECA. Old ships in the model do not have sufficient TIER rating and thus either have to be scrapped or refitted when the regulation enters into force in 2021. New built ships are generally assumed to have a TIER 3 rating. Scrubber installations for sulphur are defined for each ship type.

The average remaining lifetime for existing ships is 11 years since the average age of the current fleet is 14 years, when considering bulk, container and tanker ship types which dominate the Danish cargo fleet [49, Tab. 2.2, p. 27]. Retrofitting an old ship to comply with new regulation can possibly be an option to reduce costs. A typical refit currently ongoing to comply with sulphur regulations is the installation of a scrubber for ships with internal combustion engines running on HFO. It has to be mentioned that this results in a reduction of specific transport per fuel due to efficiency losses caused by the scrubber. Ships with internal combustion engine using HFO can also be refitted for the use of BDO, which is relatively straightforward and thus does not imply much costs. These kind of refits do not extend the lifetime of the ship or technology, but just provide different functionality.

Regarding the range options, only full electric ships are restricted to radius of 500 nautical miles, equivalent to $926 \mathrm{~km}$ (derived from [50]), all other have an unlimited range.

\subsubsection{Emission budget}

The remaining emission budget of $\mathrm{CO}_{2} \mathrm{e}$ for the temporal scope of the model is a decisive constraint in the calculation. Since there are no agreed or standardised ways of attributing GHG emissions from international shipping to countries, we have devised a method for distributing global shipping emissions and the respective remaining carbon budget to countries 2.1). We apply a global emission budget estimate by the IPCC [46, Tab. SPM.3, RCP2.6] and derive the shipping's budget by its annual estimated global GHG emission share from Olmer et al. 29.

The comparison of global maritime $\mathrm{CO}_{2}$ e emissions in 2012 with the Danish emissions in 2016 and its application to the global maritime budget leads to the Danish GHG budget (Table 1). The absolute level of Danish cargo shipping emissions of $1.2 \mathrm{Mt} \mathrm{CO}_{2} \mathrm{e}$ in 2016 is derived from the fuel specific emission operation factors, multiplied by total fuel consumed in that year. The relation of global maritime emissions in 2012 with the Danish ones in 2016 leads to a 
rather over-estimated Danish budget since the global transport demand was increasing in that period [49, Tab. 3, p. 5]. Keeping the resulting emission level constant would deplete the budgets within the next 15 years and allows for less GHG emissions compared to a linear decrease from today until 2050.

\begin{tabular}{llrr}
\hline & Unit & $\mathrm{CO}_{2}$ emissions & References \\
\hline Global budget & {$[M t]$} & 510000 & {$[46]$} \\
Global maritime budget share & {$[\%]$} & 3 & {$[29]$} \\
Global maritime budget & {$[M T]$} & 15300 & \\
Global maritime emissions in 2012 & {$[M t]$} & 961 & \\
Danish maritime emissions in 2016 & {$[M t]$} & 1.2 & {$[52,[53,[54]$} \\
Danish maritime emission share & {$[\%]$} & 0.125 & \\
Danish budget & {$[M t]$} & $\mathbf{1 9 . 1 2}$ & \\
\hline
\end{tabular}

Table 1: Derivation of $\mathrm{CO}_{2} \mathrm{e}$ emission budget from global to Danish level.

\subsection{Scenarios}

In general, all scenarios except the business as usual (BAU) and IMOscenario are modifications of the reference scenario's input parameters. The reference scenario and its modifications all comply with the carbon budget restriction. In the variations, one or a cluster of parameters are changed in a ceteris paribus manner and by the same percentage. If appropriate, changing rates are clustered due to market coupling effects. For example, electro-fuel cost parameter are all changed in the same way in the respective variation scenarios, as they all depend primarily on electricity. Additionally, the transport demand variation (TDV) scenario illustrates the possible effects of a decreasing transport demand by $30 \%$ until 2050 - else it is kept constant.

\subsubsection{Scenario data}

The development of cost and other parameters is decisive for the model results. To make the assumptions behind that transparent, the variations are expressed as percentage change rates from 2016 to 2050 (Table B.5). Derived from that number, equal annual changing rates are applied. Table B.5 shows the parameter changes and thus future development of the reference scenario.

Other decisive parameters are bio-fuel availability and transport demand. Bio-fuel availability increases from $0 \%$ in 2016 to $40 \%$ in 2050 in relation to the total fuel consumption in 2016 [55]. The transport demand stays constant based on [41, p. 18] and [56, p. 19].

\subsubsection{Scenario overview}

Table 2 provides an overview of the fourteen scenario variations and the respective modified parameters. The extent to which the respective scenario parameters are modified is stated alongside the results in section 3. 


\begin{tabular}{lll}
\hline Scenario & Description & $\begin{array}{c}\text { Modified } \\
\text { parameters }\end{array}$ \\
\hline REF & Reference scenario, based on literature & - \\
REF $(\mathrm{mp})$ & Reference scenario + methane leakage phaseout & em \\
BAU & Business as usual & eb, et \\
IMO & International Maritime Organization & eb, et \\
TDV & Transport demand variation & tdtotal \\
BATW & Cost variation of battery and wind & $\mathrm{cf}, \mathrm{ci}, \mathrm{cs}$ \\
BDO & Cost variation of bio-diesel oil & $\mathrm{cf}$ \\
CH3OH & Cost variation of methanol & $\mathrm{cf}, \mathrm{ci}, \mathrm{cs}$ \\
H2 & Cost variation of hydrogen & $\mathrm{cf}, \mathrm{ci}, \mathrm{cs}$ \\
LBG & Cost variation of liquefied bio-methane & $\mathrm{cf}, \mathrm{ci}, \mathrm{cs}$ \\
LBG $(\mathrm{mp})$ & Cost variation of liquefied bio-methane + methane leakage phaseout & $\mathrm{cf}, \mathrm{ci}, \mathrm{cs}, \mathrm{em}$ \\
LNG & Cost variation of natural gas & $\mathrm{cf}, \mathrm{ci}, \mathrm{cs}$ \\
LNG $(\mathrm{mp})$ & Cost variation of natural gas + methane leakage phaseout & $\mathrm{cf}, \mathrm{ci}, \mathrm{cs}, \mathrm{em}$ \\
NH3 & Cost variation of ammonia & $\mathrm{cf}, \mathrm{ci}, \mathrm{cs}$ \\
\hline
\end{tabular}

Table 2: Scenario overview with description and modified parameters. For additional information about scenarios see 42. (cf: fuel costs; ci: infrastructure costs; cs: ship costs; eb: emission budget; em: $\mathrm{CH}_{4}$ emissions; et: emission target; tdtotal: total transport demand)

\section{Results and Discussion}

In the business as usual scenario (BAU) no GHG regime is in place. Although $\mathrm{SO}_{X^{-}}$and $\mathrm{NO}_{X}$-restrictions are applied, no major change in fuel usage can be detected. Figure C.9 displays BAU's fuel consumption and cumulative $\mathrm{CO}_{2} \mathrm{e}$ emissions. It shows, that scrubbers instead of fuel switch are the most cost-efficient solution if no GHG restrictions are implemented. Applying the IMO goal to halve climate emissions of shipping in 2050 does not lead to significant changes except a minor switch to BDO instead of HFO (Figure 3). In comparison, the climate emission budget restriction in the reference scenario results in a significant fuel switch: Mainly hydrogen in fuel cells and BDO with scrubber in internal combustion engines are chosen (Figure 4). The comparison shows, that without any kind of climate emission restriction, the total cumulative emissions are twice as high and the IMO plans do not have a significant impact.

Due to the high level of uncertainty of cost development of infrastructure, fuel and propulsion technology of different marine fuel options, we apply a wide range of cost variations to test for its effect on fuel composition. The results are summarised in Figure C.10. Depending on the cost rate change of a specific fuel technology (x-axis), while keeping all other parameters constant, its share in the total fuel consumption from 2016-2050 (y-axis) changes significantly. The black dashed line at a cost rate change of zero represents the reference scenario. Already at a $-10 \%$ cost change rate (including fuel, ship and infrastructure costs), methanol and ammonia respectively gain relevance, reaching a dominant role at a $-20 \%$ cost change rate. Thus if the costs of either methanol or ammonia drop by $-20 \%$, these would take over the role of hydrogen as the main renewable fuel of the future. These scenario variations are illustrated in Figure 5 and Figure 6. 


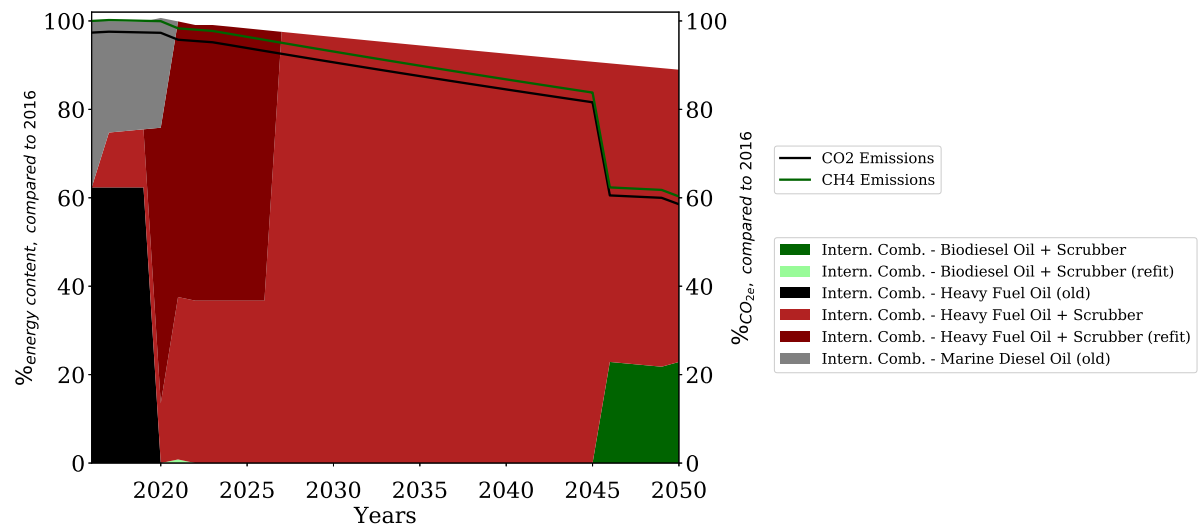

Figure 3: Fuel consumption (y-axis left) and cumulative emissions (y-axis right) in the IMO scenario, applying the climate emission target of the International Maritime Organisation for 2050 .

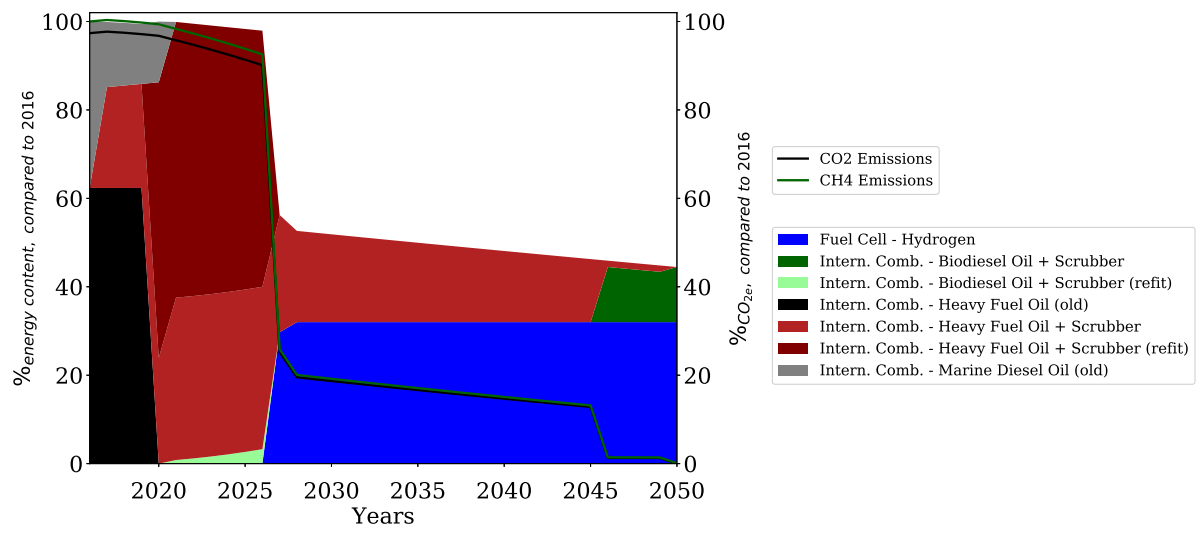

Figure 4: Fuel consumption (y-axis left) and cumulative emissions (y-axis right) in the reference scenario with a limited carbon budget. 


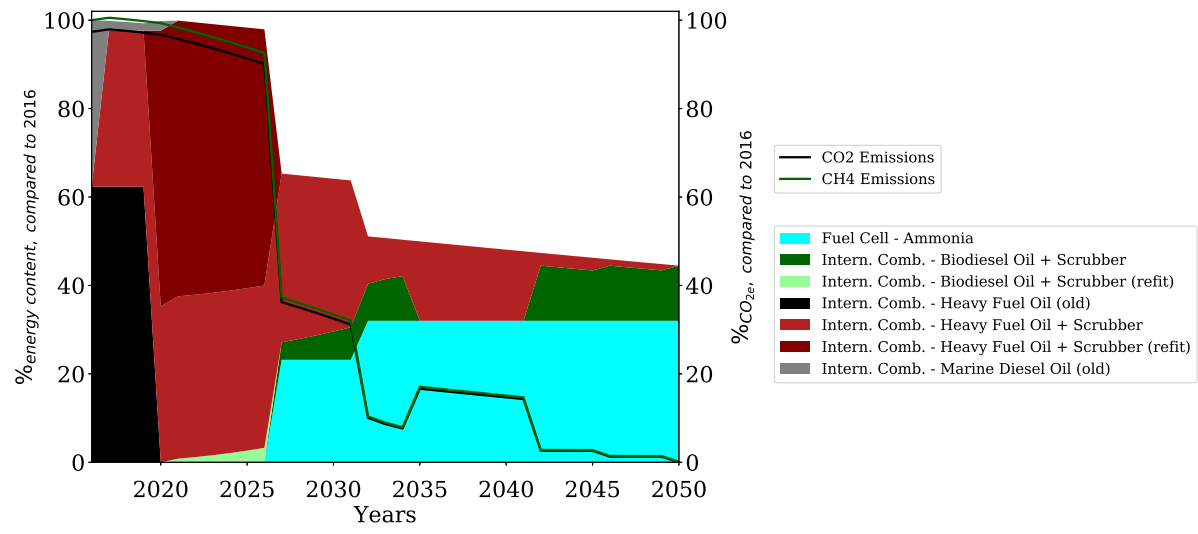

Figure 5: Fuel consumption (y-axis left) and cumulative emissions (y-axis right) in the ammonia scenario (NH3, r-20) with a limited carbon budget.

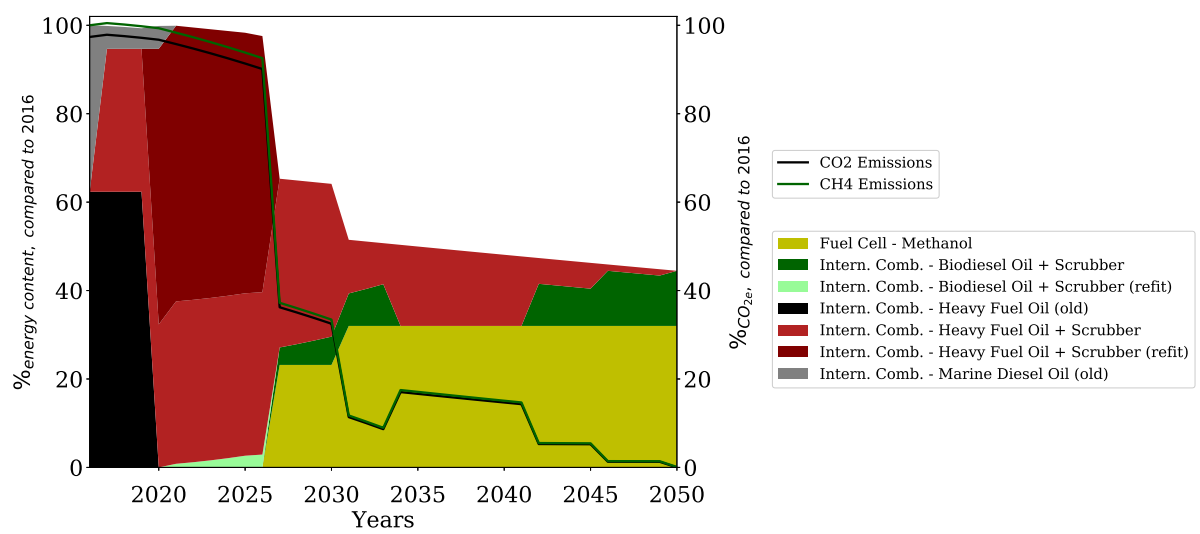

Figure 6: Fuel consumption (y-axis left) and cumulative emissions (y-axis right) in the methanol scenario $(\mathrm{CH} 3 \mathrm{OH}, \mathrm{r}-20)$ with a limited carbon budget. 
For LBG, the development of the methane leakage problem is of outstanding importance. Under the assumption that methane leakage can be coped with until 2050 (dashed line in (Figure C.10) and a cost reduction of -40\% (Figure C.11), LBG is close to hydrogen, methanol and ammonia as choice to be the dominate fuel in 2050. Contrary to that, LNG would not only require a methane leakage phase out, but also a very favourable cost development to play a major role.

Sailing cargo ships, driven by a combination of wind and electricity from batteries seem to only be cost efficient in case of a very strong drop in costs. However, the influence factors have more dimensions than just the pure battery and ship costs. In this model, it is assumed that one third of the propulsion of wind driven ships is still done by electricity. For long distance cargo, that mainly has to use the engine for manoeuvring into and out of the harbour, the wind share and potentially additional solar input can be significantly increased and thus the required battery and electricity costs reduced. Thus the conditions in our model application are rather unfavourable for wind propulsion.

For comparison, the total fuel use of all scenarios for 2016-2050 is displayed in Figure 7 and the fuel composition in the target year 2050 in Figure 8. A general efficiency increase can be seen for all carbon budget scenarios. Due to higher operational tank-to-propeller efficiency and thus a higher Tkm/GJ fuel rate, less fuel is applied in the carbon budget scenarios. Except in the transport demand scenario all supply the same transport demand.

Figure 7: Total fuel use from 2016-2050

Figure 8: Fuel composition in 2050
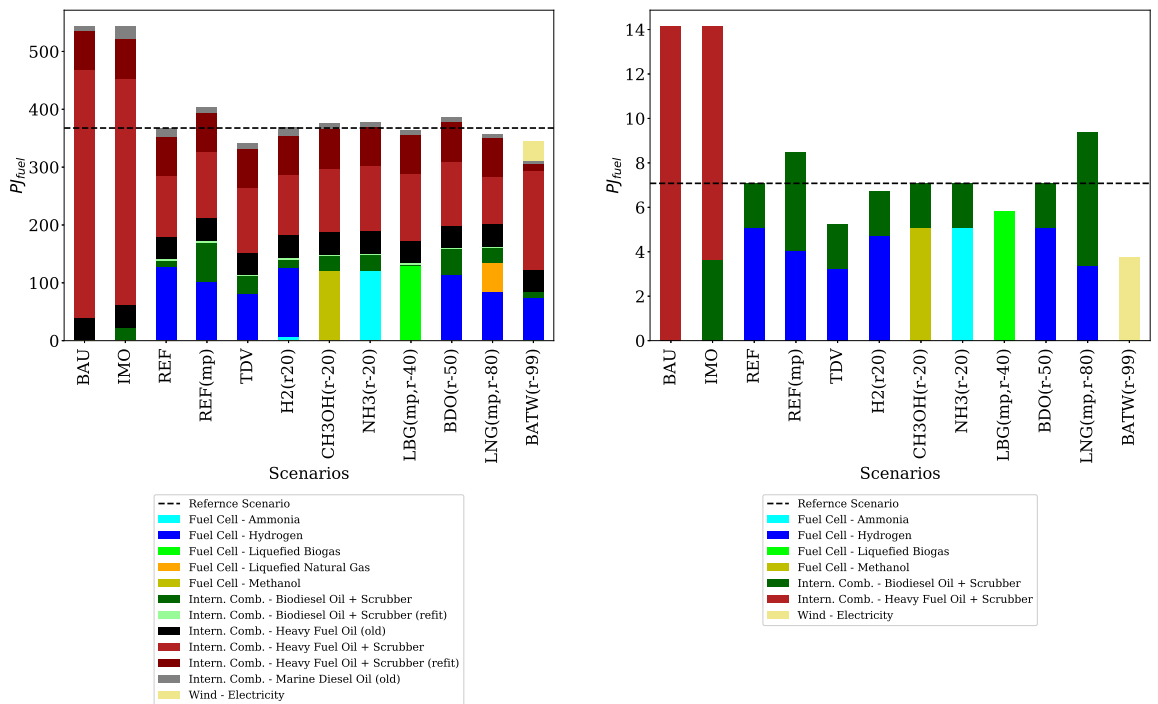

Derived from the cost differences for fuel, ship and infrastructure, a carbon price in the range of 350-450 $€_{2016} /$ ton $\mathrm{CO}_{2} \mathrm{e}$ would be required for a renewable transition of the Danish shipping sector. There are no directly comparable 
studies, but, to put our results in perspective, Raucci [57, p.197] reports similar prices of around $430 \$ /$ ton $\mathrm{CO}_{2}$ for a global transition with a global shipping carbon budget double as high as in our case. In that setting, he concludes, that hydrogen requires an emission price of $1400 \$ /$ ton $\mathrm{CO}_{2}$ to become an economic option. In contrast, a global study on country- and sector-wise $\mathrm{CO}_{2}$ abatement costs [58] represent the lower range: Although shipping is not included, road transport is indicated with about $200 € /$ ton $\mathrm{CO}_{2}$. Specific costs for climate emission abatement costs in shipping can be expected to be higher than that, since shipping poses special challenges due to high range requirements. More specifically on $\mathrm{CO}_{2}$ abatement costs for shipping, Chryssakis et al. [59], assumes costs in the range of $150-200 € /$ avoided ton $\mathrm{CO}_{2}$ if using LBG, methanol based on renewables or BDO.

The model code and most of the data references and pre-processing can also be applied for other countries, especially Europe. However, since shipping has a global perspective, the case study for Denmark already gives a good indication of the fuel shares chosen for a cost-optimal path to carbon neutrality in 2050 for the worldwide shipping. Conditions for shipping are similar, the basic parameters, technology, fuel and infrastructure costs are considered as world prices rather than reflecting local particularities.

Compared to other sectors like electricity and heat, these mitigation costs per ton $\mathrm{CO}_{2}$ e seem high, but one has to consider several points. First, our results can be interpreted as the upper bound of cost: Technologies considered are all applicable today, developments in other sectors applying similar technology options could further decrease costs and additional alternatives could evolve. Second, as shown in the demand reduction scenarios, any decrease in transport demand would save costs even beyond the proportional saving. This is due to not only fuel savings (proportional) but, also due to avoided investments in new ships (disproportionate). A decrease in transport demand especially has an effect in the period, in which new investments in ships are required and can thus avoid costs over-proportionally. And third, refits and hybrid solutions have not been considered to a great extent in the model functionality and could further decrease costs and ease the shift to different fuels.

Transport costs in the BAU scenario amount to roughly $3 €_{2016} /$ ton cargo. For climate compatible pathways they are likely to more than double. With UNCTAD [60, p. 50] reporting average transport costs of around $5 € /$ ton and including more detail, our results seem to be acceptably precise. Further, 60, p. 55] states that transport costs in developed countries are equal to $7 \%$ of the cargo's import value. Under the assumption of an equal share in BAU, cargo import values for the climate compatible pathways would increase by $6-8 \%$.

Thus, costs could get lower for the transition, but the question is also whether to talk about mitigation costs. Co-benefits like reduced air pollution have not been quantified on a monetary basis in the model and were thus not part of the optimisation. However, these could have essential health benefits, maybe even reaching mitigation gains instead of mitigation costs.

The necessary transition will not happen under current market conditions. Regulation is required urgently to bring shipping on the pathway to carbon neu- 
trality in 2050, in line with the Paris Agreement. A carbon budget for shipping worldwide, broken down to countries is a viable option to consider. Additionally, more research for alternative fuels and technologies, as well as solving crucial questions on security, infrastructure and methane leakage issues are important contributions to implement the transition to climate neutral shipping in 2050.

\section{Conclusion}

The achievement of $\mathrm{CO}_{2}$ e-neutrality in the shipping sector is of great importance for reaching the targets of the Paris Agreement. Although this goal is underrepresented in the current discussion, this study shows, that it is possible for the Danish part of international shipping to become $\mathrm{CO}_{2}$ e-neutral until 2050 with existing technologies. Regarding fuels, hydrogen, methanol and ammonia are from a socio-economic cost perspective the most compatible. Due to high uncertainties regarding future cost developments and safety requirements (esp. ammonia), there is no clear winner. Regarding technologies, fuel cells are chosen for these fuel options, the decisive parameter being the higher fuel efficiency. Although LNG is the fuel option most prominently discussed as an alternative today, it would only have a short window of opportunity, mainly because of leakage problems of methane causing high GHG emissions, and high fuel and technology costs. If this gaseous fuel is based on renewable sources, the so-called LBG can only play a role if methane leakage can be drastically reduced until 2050. The option of cargo-ships driven by a mixture of wind and electricity stored in batteries could not adequately be represented in the model setting. The evaluation of their role would need a further refinement of the calculations. The model itself has shown to be a valid tool for assessing pathways for shipping under emission restriction obligations and for assessing the threshold of different fuel options. Although the has been applied to Danish international shipping, it already gives a good indication of potential fuel shares for worldwide shipping.

The presented modelling approach indicates that either strong regulative carbon budgets or a carbon price of $350-450 € / \mathrm{t} \mathrm{CO}_{2} \mathrm{e}$ would be required to induce the necessary changes for a carbon neutral Danish shipping in 2050. This would double today's average cargo transport costs. However, due to the low share of transport cost on the value of transported goods, the average transported good would only increase by $6-8 \%$. This can be considered as the upper limit, since new fuel possibilities not reflected in this study might evolve.

\section{Acknowledgements}

This work was carried out as part of the FutureGas project (www futuregas. $\mathrm{dk}$ ) financed by the Innovation Fund Denmark [grant number 76084], of which we are grateful. We would like to thank Niels Træholt Franck and Thomas Young Hwan Westring Jensen from Energienet and Prof. Olav Hohemeyer (Europa-Universität Flensburg) for very helpful advice during development and implementation of the model and its application. 


\section{References}

[1] IPCC, Summary for Policymakers. In: Global warming of 1.5C. An IPCC Special Report on the impacts of global warming of $1.5 \mathrm{C}$ above preindustrial levels and related global greenhouse gas emission pathways, in the context of strengthening the global response to the threat of climate change, sustainable development, and efforts to eradicate poverty, Tech. Rep. October 2018, World Meteorological Organization, URL http: //www.ipcc.ch/report/sr15/, 2018.

[2] T. W. Brown, T. Bischof-Niemz, K. Blok, C. Breyer, H. Lund, B. V. Mathiesen, Response to Burden of proof: A comprehensive review of the feasibility of $100 \%$ renewable-electricity systems', Renewable and Sustainable Energy Reviews 92 (2018) 834-847, doi:10.1016/j.rser.2018.04.113.

[3] R. Salvucci, J. Tattini, M. Gargiulo, A. Lehtilä, K. Karlsson, Modelling transport modal shift in TIMES models through elasticities of substitution, Applied Energy 232 (July) (2018) 740-751, doi:10.1016/j.apenergy.2018.09. 083 .

[4] A. Schafer, Introducing behavioral change in transportation into energy/economy/environment models, Tech. Rep., The World Bank, URL http://documents.worldbank.org/curated/en/345521468323329438/ pdf/wps6234.pdf 2012.

[5] D. Gritsenko, Regulating GHG Emissions from shipping: Local, global, or polycentric approach?, Marine Policy 84 (2017) 130-133, doi:10.1016/j. marpol.2017.07.010.

[6] IMO, Adoption of the Initial IMO Strategy on Reduction of GHG Emissions From Ships and Existing IMO Activity Related To Reducing GHG Emissions in the Shipping Sector, Tech. Rep., International Maritime Organization, URL https://unfccc.int/sites/default/files/resource/250_ IMOsubmission_TalanoaDialogue_April2018.pdf, 2018.

[7] Z. Wan, A. el Makhloufi, Y. Chen, J. Tang, Decarbonizing the international shipping industry: Solutions and policy recommendations, Marine Pollution Bulletin 126 (2018) 428-435, doi:10.1016/j.marpolbul.2017.11.064.

[8] IMO, Studies on the feasibility and use of LNG as a fuel for shipping, Tech. Rep., International Maritime Organization, London, URL http: //www.imo.org/en/OurWork/Environment/PollutionPrevention/ AirPollution/Documents/LNGStudy.pdf 2016.

[9] DNV GL, LNG as a ship fuel - Latest developments and projects in the LNG industry, Tech. Rep., Det Norske Veritas group, URL https://www. dnvgl.com/maritime/lng/index.html, 2015. 
[10] S. Brynolf, M. Magnusson, E. Fridell, K. Andersson, Compliance possibilities for the future ECA regulations through the use of abatement technologies or change of fuels, Transportation Research Part D: Transport and Environment 28 (2014) 6-18, doi:10.1016/j.trd.2013.12.001

[11] DNV GL, Alternative Fuels for Shipping, Tech. Rep., Det Norske Veritas group, URL https://transportemaritimoglobal.files.wordpress. com/2014/01/dnv-gl-alternative-fuel-2014-positionpaper.pdf, 2014 .

[12] H. Thomson, J. J. Corbett, J. J. Winebrake, Natural gas as a marine fuel, Energy Policy 87 (2015) 153-167, doi:10.1016/j.enpol.2015.08.027

[13] IEA, Outlook for Natural Gas - Excerpt from World Energy Outlook, Tech. Rep., International Energy Agency, URL http://webstore.iea.org/ world-energy-outlook-2017-excerpt-outlook-for-natural-gas, 2017.

[14] R. A. Alvarez, D. Zavala-Araiza, D. R. Lyon, D. T. Allen, Z. R. Barkley, A. R. Brandt, K. J. Davis, S. C. Herndon, D. J. Jacob, A. Karion, E. A. Kort, B. K. Lamb, T. Lauvaux, J. D. Maasakkers, A. J. Marchese, M. Omara, S. W. Pacala, J. Peischl, A. L. Robinson, P. B. Shepson, C. Sweeney, A. Townsend-Small, S. C. Wofsy, S. P. Hamburg, Assessment of methane emissions from the U.S. oil and gas supply chain, Science doi: 10.1126/science.aar7204.

[15] D. A. Hagos, E. O. Ahlgren, Well-to-wheel assessment of natural gas vehicles and their fuel supply infrastructures Perspectives on gas in transport in Denmark, Transportation Research Part D: Transport and Environment 65 (2018) 14-35, ISSN 1361-9209, doi:10.1016/j.trd.2018.07.018.

[16] J. J. Corbett, James J., Thomson, Heather, Winebrake, Methane Emissions from Natural Gas Bunkering Operations in the Marine Sector: A Total Fuel Cycle Approach, Tech. Rep., Prepared for U.S. Department of Transportation Maritime Administration, URL https://www.researchgate.net/publication/311790113_Methane_ emissions_from_natural_gas_use_in_the_marine_sector, 2015.

[17] Stenersen, Dag, Thonstad, Ole, GHG and NOx emissions from gas fuelled engines, Tech. Rep., SINTEF OC2017 F-108, URL https://www.nho.no/siteassets/nox-fondet/rapporter/2018/ methane-slip-from-gas-engines-mainreport-1492296.pdf, 2017.

[18] S. Brynolf, E. Fridell, K. Andersson, Environmental assessment of marine fuels: liquefied natural gas, liquefied biogas, methanol and bio-methanol, Journal of Cleaner Production 74 (2014) 86-95, doi:10.1016/j.jclepro.2014. 03.052 . 
[19] DNV GL, Assessment of selected alternative fuels and technologies, Tech. Rep., Det Norske Veritas group, URL https://www.dnvgl.com/ maritime/publications/alternative-fuel-assessment-download. html, 2018.

[20] P. Gilbert, From reductionism to systems thinking: How the shipping sector can address sulphur regulation and tackle climate change, Marine Policy 43 (2014) 376-378, doi:10.1016/j.marpol.2013.07.009.

[21] E. Fridell, Emissions and Fuel Use in the Shipping Sector, in: R. Bergqvist, J. Monios (Eds.), Green Ports, Elsevier, ISBN 978-0-12-814054-3, 19-33, doi:10.1016/B978-0-12-814054-3.00002-5, URL http://www. sciencedirect.com/science/article/pii/B9780128140543000025,

2019.

[22] S. Horvath, M. Fasihi, C. Breyer, Techno-economic analysis of a decarbonized shipping sector: Technology suggestions for a fleet in 2030 and 2040, Energy Conversion and Management 164 (2018) 230-241, doi: 10.1016/j.enconman.2018.02.098.

[23] IRENA, Renewable energy options for shipping - Technology brief, Tech. Rep., International Renewable Energy Agency, URL http://www.irena.org/publications/2015/Feb/ Renewable-Energy-Options-for-Shipping, 2015.

[24] S. Jafarzadeh, I. B. Utne, A framework to bridge the energy efficiency gap in shipping, Energy 69 (2014) 603-612, ISSN 0360-5442, doi:10.1016/ j.energy.2014.03.056

[25] H. Chi, G. Pedrielli, S. H. Ng, T. Kister, S. Bressan, A framework for realtime monitoring of energy efficiency of marine vessels, Energy 145 (2018) 246-260, doi:10.1016/j.energy.2017.12.088.

[26] F. Baldi, C. Gabrielii, A feasibility analysis of waste heat recovery systems for marine applications, Energy 80 (2015) 654-665, doi:10.1016/j.energy. 2014.12 .020

[27] V. N. Armstrong, Vessel optimisation for low carbon shipping, Ocean Engineering 73 (2013) 195-207, doi:10.1016/j.oceaneng.2013.06.018.

[28] H. Lindstad, G. S. Eskeland, Low carbon maritime transport: How speed, size and slenderness amounts to substantial capital energy substitution, Transportation Research Part D: Transport and Environment 41 (2015) 244-256, doi:10.1016/j.trd.2015.10.006.

[29] N. Olmer, B. Comer, B. Roy, X. Mao, D. Rutherford, Greenhouse Gas Emissions From Global Shipping, 2013-2015, Tech. Rep. October, icct - The International Council on Clean Transportation, URL https://www.theicct.org/publications/ GHG-emissions-global-shipping-2013-2015, 2017. 
[30] Lloyd's Register, Low carbon pathways 2050, Tech. Rep., Lloyd's Register, URL http://www.lr.org/en/projects/low-carbon-pathways-2050. aspx, 2016.

[31] E. A. Bouman, E. Lindstad, A. I. Rialland, A. H. Strømman, State-ofthe-art technologies, measures, and potential for reducing GHG emissions from shipping A review, Transportation Research Part D: Transport and Environment 52 (2017) 408-421, doi:10.1016/j.trd.2017.03.022.

[32] T. Smith, C. Raucci, S. Haji Hosseinloo, I. Rojon, J. Calleya, S. Suarez de la Fuente, P. Wu, K. Palmer, CO2 Emissions from International Shipping: Possible reduction targets and their associated pathways, Tech. Rep., UMAS, doi:10.1002/yd.20075, URL https://u-mas.co.uk/LinkClick. aspx?fileticket=na3ZeJ8Vp1Y\%3D\&portalid=0, 2016.

[33] Lloyd's Register and UMAS, Zero Emission Vessels, what needs to be done?, Tech. Rep. May, Sustainable Shipping Initiative, URL https://danskemaritime.dk/wp-content/uploads/2017/03/SSI_ ZEV_Report_Final-May-2018.pdf, 2018.

[34] Lloyd's Register, Zero-Emission Vessels 2030 . How do we get there ?, Tech. Rep., Lloyd's Register, URL http://www.lr.org/en/projects/ zero-emission-vessels-2030.aspx, 2017.

[35] H. E. Lindstad, G. S. Eskeland, A. Rialland, Batteries in offshore support vessels Pollution, climate impact and economics, Transportation Research Part D: Transport and Environment 50 (2017) 409-417, doi:10.1016/j.trd. 2016.11.023.

[36] S. Mander, Slow steaming and a new dawn for wind propulsion: A multilevel analysis of two low carbon shipping transitions, Marine Policy 75 (2017) 210-216, doi:10.1016/j.marpol.2016.03.018.

[37] H. Winnes, L. Styhre, E. Fridell, Reducing GHG emissions from ships in port areas, Research in Transportation Business \& Management 17 (2015) 73-82, doi:10.1016/j.rtbm.2015.10.008.

[38] Y. Shi, Reducing greenhouse gas emissions from international shipping: Is it time to consider market-based measures?, Marine Policy 64 (2016) 123-134, doi:10.1016/j.marpol.2015.11.013.

[39] O. Dessens, A. Anger, T. Barker, J. Pyle, Effects of decarbonising international shipping and aviation on climate mitigation and air pollution, Environmental Science \& Policy 44 (2014) 1-10, doi:10.1016/j.envsci.2014. 07.007.

[40] European Commission, Reducing emissions from the shipping sector, URL https://ec.europa.eu/clima/policies/transport/shipping_ en\#tab-0-0, 2018. 
[41] ITF (International Transport Forum), Decarbonising Maritime Transport - Pathways to zero-carbon shipping by 2035, Tech. Rep., OECD, Paris, URL https://www.itf-oecd.org/sites/default/files/docs/ decarbonising-maritime-transport.pdf, 2018.

[42] T. ben Brahim, Future Marine Fuels - A Danish Case Study on Climate Compatible Energy Pathways, Master's Thesis, University of Flensburg, URL https://github.com/futuremarinefuels/denmark/blob/master/ master_thesis_benbrahim_final.pdf, 2018.

[43] IMO (International Maritime Organization), MARPOL ANNEX VI, Regulation 13, URL http://www.imo.org/en/ourwork/environment/ pollutionprevention/airpollution/pages/nitrogen-oxides-(nox) --regulation-13.aspx, 2008.

[44] IMO (International Maritime Organization), MARPOL ANNEX VI, Regulation 14, URL http://www.imo.org/en/OurWork/environment/ pollutionprevention/airpollution/pages/sulphur-oxides-(sox) --regulation-14.aspx, 2008.

[45] IPCC, 2.10.2 Direct Global Warming Potentials - AR4 WGI Chapter 2: Changes in Atmospheric Constituents and in Radiative Forcing, URL https://www.ipcc.ch/publications_and_data/ar4/wg1/en/ ch2s2-10-2.html, 2007.

[46] T. F. Stocker, D. Qin, G.-K. Plattner, M. Tignor, S. K. Allen, J. Boschung, A. Nauels, Y. Xia, V. Bex, P. M. Midgley, 2013: Summary for Policymakers. In: Climate Change 2013: The Physical Science Basis. Contribution of Working Group I to the Fifth Assessment IPCC, Report of the Intergovernmental Panel on Climate Change, Tech. Rep., Cambridge University, Cambridge, United Kingdom and New York, NY, USA, URL https://www .ipcc.ch/pdf/assessment-report/ar5/wg1/WG1AR5_ SPM_FINAL.pdf, 2013.

[47] T. ben Brahim, A Danish Case Study on Climate Compatible Energy Pathways, Model code and description, https://github.com/ futuremarinefuels/denmark, 2018.

[48] T. ben Brahim, futuremarinefuels/denmark 1.4, doi:10.5281/ZENODO. 1476417, 2018.

[49] UNCTAD, Review of Maritime Transport 2017, Tech. Rep., United Nations Conference on Trade and Development, New York, Geneva, URL http: //unctad.org/en/PublicationsLibrary/rmt2017_en.pdf, 2017.

[50] T. Stensvold, Elektriske pramme skal overtage lastbilernes containere (in Danish), URL https://ing.dk/artikel/ elektriske-pramme-skal-overtage-lastbilernes-containere-209952 2018. 
[51] T. W. P. Smith, J. P. Jalkanen, B. A. Anderson, J. J. Corbett, J. Faber, S. Hanayama, E. O'Keeffe, S. Parker, L. Johansson, L. Aldous, C. Raucci, M. Traut, S. Ettinger, D. Nelissen, D. S. Lee, S. Ng, A. Agrawal, J. J. Winebrake, A. Hoen, M., Third IMO Greenhouse Gas Study 2014, Tech. Rep., URL http: //www.imo.org/en/OurWork/Environment/PollutionPrevention/ AirPollution/Documents/Third\%20Greenhouse \%20Gas\%20Study/GHG3\% 20Executive\%20Summary\%20and\%20Report.pdf, 2014.

[52] H. O. Kristensen, Energy Demand And Exhaust Gas Emissions of Marine Engines, Tech. Rep., Technical University of Denmark and University of Southern Denmark, URL https://www.scribd.com/document/ 177802839/Energy-Demand-and-Emissions-of-Marine-Engines, 2012.

[53] Eurostat, Table mar_go_am_dk: Gross weight of goods transported to/from main ports - Denmark - annual data: Selected years, 2015 - 2016, URL http://appsso.eurostat.ec.europa.eu/nui/show.do? dataset=mar_go_am_dk\&lang=en, 2018.

[54] A. Wisdom, Pathways to low carbon maritime transportation in Denmark, Master thesis, Technical University of Denmark, 2017.

[55] DEA (Danish Energy Agency), Annual and monthly statistics, URL https://ens.dk/en/our-services/ statistics-data-key-figures-and-energy-maps/ annual-and-monthly-statistics, 2016.

[56] C. Rex, M. Andersen, N. Kristensen, Shipping Market Review - May 2017, Tech. Rep. May, Danish Ship Finance, URL https://www.shipfinance. dk/media/1735/shipping-market-review-may-2017.pdf 2017.

[57] C. Raucci, The potential of hydrogen to fuel international shipping, Ph.D. thesis, University College London, URL http://discovery.ucl.ac.uk/ 1539941/, 2017.

[58] OECD, Effective Carbon Rates: Pricing CO2 through Taxes and Emissions Trading Systems, OECD Publishing, Paris, doi:10.1787/9789264260115-en, 2016.

[59] C. Chryssakis, H. W. Brinks, A. C. Brunelli, T. P. Fuglseth, M. Lande, L. Laugen, T. Longva, B. Raeissi, H. A. Tvete, Low Carbon Shipping Towards 2050, Tech. Rep., DNVGL, URL https://www.dnvgl.com/ publications/low-carbon-shipping-towards-2050-93579, 2017.

[60] UNCTAD, Review of Maritime Transport 2015, October, United Nations Publications, New York, Geneva, URL https://unctad.org/en/ PublicationsLibrary/rmt2015_en.pdf, 2015.

[61] BIX (Bunker Index), Bunker Index Prices, URL http://www . bunkerindex.com/news/article.php?article_id=18387, 2018. 
[62] P. Gilbert, C. Walsh, M. Traut, U. Kesieme, K. Pazouki, A. Murphy, Assessment of full life-cycle air emissions of alternative shipping fuels, Journal of Cleaner Production 172 (2018) 855-866, doi:10.1016/j.jclepro.2017.10. 165.

[63] S. Bengtsson, E. Fridell, K. Andersson, Environmental assessment of two pathways towards the use of biofuels in shipping, Energy Policy 44 (2012) 451-463, ISSN 03014215, doi:10.1016/j.enpol.2012.02.030, URL http:// dx.doi.org/10.1016/j.enpol.2012.02.030.

[64] K. Andersson, M. Márquez Salazar, Methanol as a Marine Fuel, Tech. Rep., Methanol Institute, URL http://www.methanol.org/wp-content/uploads/2018/03/ FCBI-Methanol-Marine-Fuel-Report-Final-English.pdf, 2015.

[65] EnergiNet, LNG Plant Calculations - personal communication., 2018.

[66] S. Brynolf, M. Taljegard, M. Grahn, J. Hansson, Electrofuels for the transport sector: A review of production costs, Renewable and Sustainable Energy Reviews 81 (February 2017) (2018) 1887-1905, doi:10.1016/j.rser.2017. 05.288, URL $10.1016 /$ j.rser.2017.05.288.

[67] E. R. Morgan, J. F. Manwell, J. G. Mcgowan, Sustainable Ammonia Production from U.S. Offshore Wind Farms: A Techno-Economic Review, ACS Sustainable Chem. Eng. 5 (11), doi:10.1021/acssuschemeng.7b02070.

[68] D. Vree, Haalbaarheidsonderzoek Walstroom Amsterdam - Elektrotechnisch en financieel haalbaarheidsonderzoek voor de riviercruise en zeecruise terminals (in Dutch), Tech. Rep., HASKONING NEDERLAND B.V., Amsterdam, URL http://www.ops.wpci.nl/_images/_downloads/ _original/1264152276_2008eindrapportwalstroomhavenamsterdam. pdf, 2008.

[69] R. McGill, W. Remley, K. Winther, Alternative Fuels for Marine Applications, Tech. Rep. AMF Annex 41, IEA Advanced Motor Fuels Implementing Agreement, doi:10.2478/v10161-012-0024-9, 2013.

[70] M. M. El Gohary, Environmental analysis of present and future fuels in 2D simple model marine gas tubines, International Journal of Naval Architecture and Ocean Engineering 5 (4) (2013) 559-568, doi:10.2478/ IJNAOE-2013-0153.

[71] L. van Biert, M. Godjevac, K. Visser, P. V. Aravind, A review of fuel cell systems for maritime applications, Journal of Power Sources 327 (X) (2016) 345-364, doi:10.1016/j.jpowsour.2016.07.007.

[72] U.S. Department of Energy, Fuel cells fact sheet, Fuel cells fact sheet URL https://www.energy.gov/sites/prod/files/2015/11/f27/fcto_ fuel_cells_fact_sheet.pdf. 
[73] JAE-KNY/MDA, Energinet's Analysis Assumptions 2017, Tech. Rep. Doc. no. 16/15822-51, Energinet, Fredericia, URL https: //en.energinet.dk/Analysis-and-Research/Analysis-assumptions/ Analysis-assumptions-2017, 2017. 


\title{
Appendix A. Equations
}

\author{
Appendix A.0.1. Nomenclature
}

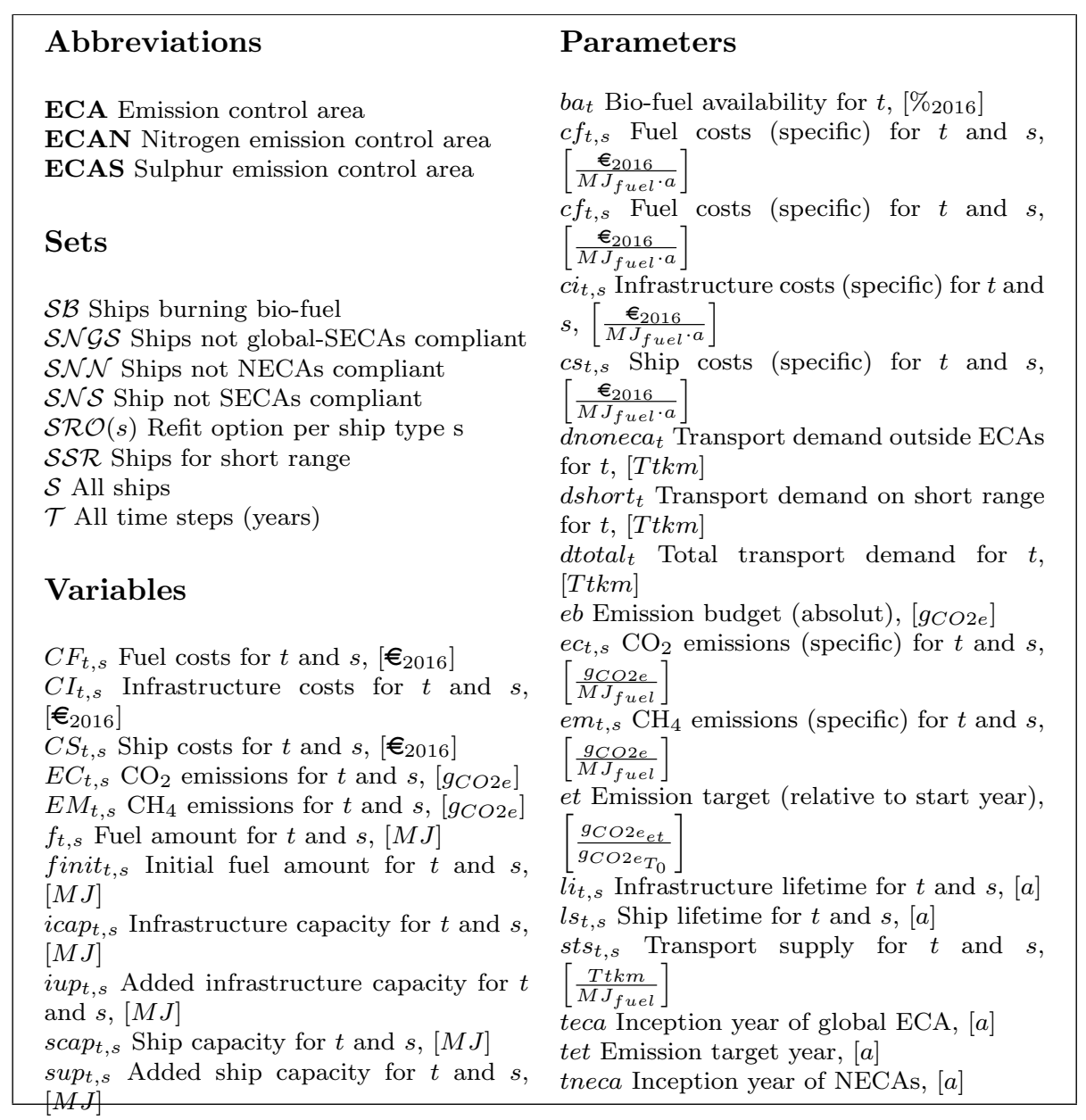

Nomenclature list.

\section{Appendix A.0.2. Objective equation}

The objective equation minimises total system expenditures over all time steps and ship types (aggregated by main engine and fuel). It comprises the sum of costs for fuel consumption, additional infrastructure as well as ship capacity for all years (35 time steps in the described application). Costs for fixed assets - fuel infrastructure (CI) and ships (CS) - are given as annuities and account only with the annual added capacities. The value of the existing amount in the 
start year $\left(\right.$ finit $_{t, s}$ in $\left.T_{0}\right)$ is not included in $C I$ and $C S$.

$$
\min . \sum_{\forall t \in T} \sum_{\forall s \in S}\left(C F_{t, s}+C I_{t, s}+C S_{t, s}\right)
$$

subject to (s.t.)

$$
\begin{aligned}
& C F_{t, s} \geq f_{t, s} \cdot c f_{t, s} \\
& C I_{t, s} \geq\left(\text { iupp }_{t, s}-\text { finit }_{t, s}\right) \cdot l i_{s} \cdot c i_{t, s}, \forall t \in T_{0} \\
& C I_{t, s} \geq \text { iup }_{t, s} \cdot l i_{s} \cdot c i_{t, s}, \forall t \in T_{>0} \\
& C S_{t, s} \geq\left(\sup _{t, s}-f i n i t_{t, s}\right) \cdot l s_{s} \cdot c s_{t, s}, \forall t \in T_{0} \\
& C S_{t, s} \geq \sup _{t, s} \cdot l s_{s} \cdot c s_{t, s}, \forall t \in T_{>0}
\end{aligned}
$$

Appendix A.0.3. Constraints on fuel utilisation, infrastructure and ship capacity

Fuel constraints may apply for a selection of ship types and years in the model (Equation A.7). With regard to infrastructure and ships, only the incremental capacity is cost effective while taking into account expiry dates of existing capacities. The expiry dates relate to the technical lifetimes, which differ between ships and infrastructure of same type.

Infrastructure capacity: Defined as the sum of all additional fuel infrastructure built during the elapsed technical lifetime.

$$
\operatorname{icap}_{t, s} \leq \sum_{\mathbf{x}}^{t-1}\left(\operatorname{iup}_{x, s}\right), \forall t \in T_{>0}, \forall s \in S
$$

s.t.

$$
\begin{aligned}
& x=T_{0}, \forall t \leq\left(l i_{s}+T_{0}-1\right) \\
& x=t-l i_{s}+1, \forall t>\left(l i_{s}+T_{0}-1\right)
\end{aligned}
$$

Additional infrastructure: Additional fuel infrastructure in order to supply the fleet.

$$
\operatorname{iup}_{t, s} \geq f_{t, s}-i c a p_{t, s}, \forall t \in T_{>0}, \forall s \in S
$$

Existing ships: Defined as the sum of all additional shipping capacity build during the elapsed technical lifetime.

$$
\operatorname{scap}_{t, s} \leq \sum_{\mathbf{x}}^{t-1}\left(\sup _{x, s}\right), \forall t \in T_{>0}, \forall s \in S
$$

s.t.

$$
\begin{aligned}
& x=T_{0}, \forall t \leq\left(l s_{s}+T_{0}-1\right) \\
& x=t-l s_{s}+1, \forall t>\left(l s_{s}+T_{0}-1\right)
\end{aligned}
$$


Additional ships: Additional ships in order to supply the cargo transport demand.

$$
\sup _{t, s} \geq f_{t, s}-\operatorname{scap}_{t, s}, \forall t \in T_{>0}, \forall s \in S
$$

Refit capacity: Defines for each year the old ships' capacity possible to refit.

$$
\begin{array}{r}
f_{t, s}+f_{t, r}-f_{T_{0}, s} \leq 0, \forall t \in T_{<\left(T_{0}+l s_{s}\right)}, \forall s, r \in S R O \\
f_{t, s}+f_{t, r}=0, \forall t \in T_{\geq\left(T_{0}+l s_{s}\right)}, \forall s, r \in S R O
\end{array}
$$

Bio-fuel capacity: Defines for each year the upper limit of bio-fuel available based on own assumptions.

$$
\sum_{\forall s \in S B}\left(f_{t, s}\right)-b a_{t} \cdot \text { finit }_{T_{0}} \leq 0, \forall t \in T
$$

\section{Appendix A.0.4. Constraints on transport demand}

Transport demand constraints may apply for a selection of ship types and years in the model, depending on the range category - either short or long and the emission regulations - in- or outside emission control areas (ECA).

Total transport demand: Defines for each year that the total transport supply by all ships must be greater or equal to the total transport demand.

$$
d_{t o t a l} \leq \sum_{\forall s \in S}\left(f_{t, s} \cdot s t s_{t, s}\right), \forall t \in T
$$

Short transport demand: Defines for each year the maximum transport supply of all ships categorised as short range $(926 \mathrm{~km})$.

$$
\text { dshort }_{t} \geq \sum_{\forall s \in S S R}\left(f_{t, s} \cdot s t s_{t, s}\right), \forall t \in T
$$

Non-ECAS transport demand: Defines for each year the maximum transport supply of all ships only allowed for operation outside of the ECAs.

$$
\text { dnoneca }_{t} \geq \sum_{\forall s \in S N S}\left(f_{t, s} \cdot s t s_{t, s}\right), \forall t \in T
$$

Appendix A.0.5. Constraints on emissions

Emission constraints may apply for a selection of ship types and years in the model. The constraint set imposes limitations to the deployment of certain fuel types in the model based on the defined $\mathrm{CO}_{2}$ e budget and target as well as the legal restrictions for $\mathrm{SO}_{X}$ and $\mathrm{NO}_{X}$ as defined by the IMO. 
Emission budget: Defines the maximal amount of accumulated total GHG emissions.

$$
e b \geq \sum_{\forall t \in T} \sum_{\forall s \in S}\left(E C_{t, s}+E M_{t, s}\right)
$$

s.t.

$$
\begin{aligned}
E C_{t, s} & =f_{t, s} \cdot e c_{t, s}, \forall t \in T, \forall s \in S \\
E M_{t, s} & =f_{t, s} \cdot e m_{t, s}, \forall t \in T, \forall s \in S
\end{aligned}
$$

Emission target: Defines the amount of GHG emissions allowed in the target year, based on a percentage reduction from the start year.

$$
\frac{\sum_{\forall s \in S}\left(E C_{T_{0}, s}+E M_{T_{0}, s}\right)}{\sum_{\forall s \in S}\left(E C_{t, s}+E M_{t, s}\right)} \cdot e t \geq 1, \forall t \in T_{\geq\left(t e t-T_{0}\right)}
$$

Global $S O_{X}$ regulations: Defines the set of ships as of 2020 prohibited to operate globally with respect to global $\mathrm{SO}_{X}$ regulations.

$$
f_{t, s}=0, \forall t \in T_{\geq \text {teca }-T_{0}}, \forall s \in S N G S
$$

$N O_{X}$ regulations: Defines the set of ships as of 2021 prohibited to operate within ECAN.

$$
f_{t, s}=0, \forall t \in T_{\geq \text {tneca- }}, \forall s \in S N N
$$




\section{Appendix B. Tables}

\begin{tabular}{|c|c|c|c|c|c|c|c|c|}
\hline Fuel type & $\begin{array}{r}\mathrm{cf} \\
{\left[\frac{E U R_{2016}}{G, J_{\text {fuel }}}\right]} \\
\end{array}$ & $\begin{array}{r}\mathrm{ci} \\
{\left[\frac{E U R_{2016}}{G J_{f u e l}}\right]} \\
\end{array}$ & $\begin{array}{r}\mathrm{cf}+\mathrm{ci} \\
\left.\frac{E U R_{2016}}{G J_{f u e l}}\right] \\
\end{array}$ & $\begin{array}{r}\mathrm{ec}(\mathrm{w} 2 \mathrm{t}) \\
{\left[\frac{g_{C O 2}}{M J_{f u e l}}\right]}\end{array}$ & $\begin{array}{l}\mathrm{em}(\mathrm{w} 2 \mathrm{t}) \\
{\left[\frac{g_{C H 4}}{M J_{f u e l}}\right]}\end{array}$ & $\begin{array}{r}\text { sulphur content } \\
{\left[\%_{\text {mass }}\right]}\end{array}$ & $\begin{array}{r}\text { li } \\
{[a]}\end{array}$ & References \\
\hline $\mathrm{HFO}$ & - & - & 6.547 & 8.148 & 0.090 & 2.9525 & 40 & 61, 62, 63. 18 \\
\hline MDO & - & - & 12.775 & 7.728 & 0.090 & 0.7500 & 40 & 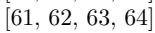 \\
\hline $\mathrm{BDO}$ & - & - & 24.240 & 0 & 0.030 & 0.1498 & 40 & 33. 63 \\
\hline LNG & 4.888 & 0.139 & - & 6.600 & 0.033 & 0.0500 & 36 & 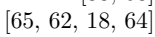 \\
\hline LBG & 27.847 & 1.599 & - & 0 & 0.130 & 0.0750 & 25 & 66.63 \\
\hline $\mathrm{H} 2$ & 20.885 & 1.199 & - & 0 & 0 & 0 & 25 & 66 \\
\hline $\mathrm{CH} 3 \mathrm{OH}$ & 29.240 & 1.679 & - & 0 & 0.042 & 0.0912 & 25 & 66. 18 \\
\hline NH3 & 26.803 & 1.802 & - & 0 & 0 & 0 & 20 & 67 \\
\hline ELEC & 13.889 & 2.929 & - & 0 & 0 & 0 & 20 & 68 \\
\hline
\end{tabular}

Table B.3: Fuel type data for each parameter (for abbreviations see the nomenclature list in appendix Appendix A.0.1. Further explanation of data can be found in [42].

\begin{tabular}{|c|c|c|c|c|c|c|c|c|c|c|c|c|}
\hline Ship-type & Range & $\begin{array}{r}1 \mathrm{~s} \\
{[a]}\end{array}$ & $\begin{array}{r}\mathrm{fa}_{2016} \\
{\left[P J_{\text {fuel }}\right]}\end{array}$ & {$\left[\frac{T t k m}{\mathrm{ts}}\right]$} & $\begin{array}{r}\mathrm{cs} \\
{\left[\frac{E U R_{2016}}{G J_{f u c l}}\right]}\end{array}$ & $\left.\begin{array}{c}\mathrm{ec}(\mathrm{t} 2 \mathrm{p}) \\
{\left[\frac{g C O 2}{M J_{\text {fuel }}}\right.}\end{array}\right]$ & $\begin{array}{l}\mathrm{em}(\mathrm{t} 2 \mathrm{p}) \\
{\left[\frac{g_{\mathrm{CHA}}}{M J_{f u \in t}}\right]}\end{array}$ & Refit & Refit opt. & Tier & Scrubber & References \\
\hline IC HFO (old) & long & 11 & 9.93 & 9.69 & 8.72 & 76.06 & 0.00045 & yes & IC HFO (refit) & 0 & no & 49.53 .54 .52 .56 \\
\hline IC MDO (old) & long & 11 & 5.99 & 9.40 & 8.45 & 74.36 & 0.00045 & yes & IC BDO (refit) & 0 & yes & $49,53,54,52,56$ \\
\hline IC HFO & long & 25 & 0 & 9.40 & 8.45 & 75.90 & 0.00045 & no & - & 3 & yes & 49.52 .56 \\
\hline IC MDO & long & 25 & 0 & 9.40 & 8.45 & 74.32 & 0.00045 & no & - & 3 & yes & 49. 52,56 \\
\hline IC HFO (refit) & long & 11 & 0 & 9.40 & 0.02 & 75.90 & 0.00045 & no & - & 3 & yes & 49. 69 \\
\hline IC BDO (refit) & long & 11 & 0 & 9.40 & 0 & 0 & 0.00045 & no & - & 3 & yes & 49,54 \\
\hline IC BDO & long & 25 & 0 & 9.40 & 8.45 & 0 & 0.00045 & no & - & 3 & yes & 49, 63 \\
\hline IC LNG & long & 25 & 0 & 10.13 & 96.98 & 54.36 & 0.71000 & no & - & 3 & no & $49,52,56$ \\
\hline IC LBG & long & 25 & 0 & 10.13 & 96.98 & 0 & 0.79000 & no & - & 3 & no & 49. 63 \\
\hline IC H2 & long & 25 & 0 & 10.13 & 109.29 & 0 & 0 & no & - & 3 & no & 49.70 \\
\hline IC CH3OH & long & 25 & 0 & 10.13 & 109.29 & 0 & 0.79000 & no & - & 3 & no & 49, 64,18 \\
\hline IC NH3 & long & 25 & 0 & 10.13 & 109.29 & 0 & 0 & no & - & 3 & no & \begin{tabular}{|l|l|l|} 
& 49
\end{tabular} \\
\hline FC LNG & long & 25 & 0 & 22.47 & 134.80 & 54.36 & 0.22763 & no & - & 3 & no & 49.71 \\
\hline FC LBG & long & 25 & 0 & 22.47 & 134.80 & 0 & 0.22763 & no & - & 3 & no & 49,71 \\
\hline $\mathrm{FC} \mathrm{H} 2$ & long & 25 & 0 & 22.47 & 134.80 & 0 & 0 & no & - & 3 & no & 49,72 \\
\hline $\mathrm{FC} \mathrm{CH} 3 \mathrm{OH}$ & long & 25 & 0 & 22.47 & 134.80 & 0 & 0.22763 & no & - & 3 & no & 49,71 \\
\hline FC NH3 & long & 25 & 0 & 22.47 & 134.80 & 0 & 0 & no & - & 3 & no & 49 \\
\hline EM ELEC & short & 30 & 0 & 11.86 & $1,047.05$ & 0 & 0 & no & - & 3 & no & 9 \\
\hline WIND ELEC & long & 30 & 0 & 35.58 & $2,094.11$ & 0 & 0 & no & - & 3 & no & \\
\hline
\end{tabular}

Table B.4: Ship type data for each specific parameter (for abbreviations see the nomenclature list in Appendix A.0.1. Further explanation and references of data can be found in [42. 


\begin{tabular}{lrlr}
\hline $\begin{array}{l}\text { Modified } \\
\text { para- } \\
\text { meters }\end{array}$ & $\begin{array}{r}\text { Percentage } \\
\text { change } \\
2016-2050\end{array}$ & Affected Technologies & References \\
\hline ic & -20 & LNG,LBG,H2,CH3OH,NH3,ELEC & 66. fig. 6, p. 13] \\
& 110 & HFO,MDO,BDO,LNG & 73. fig. 13, p. 3] \\
cf & -20 & LBG,H2,CH3OH,NH3,ELEC & [66. fig. 6, p. 13] \\
& -40 & Internal combustion: LNG,LBG,H2,CH3OH,NH3 & {$[56]$} \\
cs & -50 & Fuel cell: LNG,LBG,H2,CH3OH,NH3 \\
& -75 & Eletric motor, WIND: ELEC \\
ts & +15 & All except old ships & \\
ec & -10 & IC: HFO,MDO,LNG; FC: LNG & 51. tab. 51, p. 282] \\
em & -10 & IC: HFO,MDO,BDO,LNG; FC: LNG,LBG & [51. tab. 51, p. 282] \\
\hline
\end{tabular}

Table B.5: Change of fuel and ship specific parameters from 2016 to 2050 in the Reference scenario (for abbreviations see the nomenclature list in Appendix A.0.1. For additional information about scenarios see 42 .

\section{Appendix C. Figures}

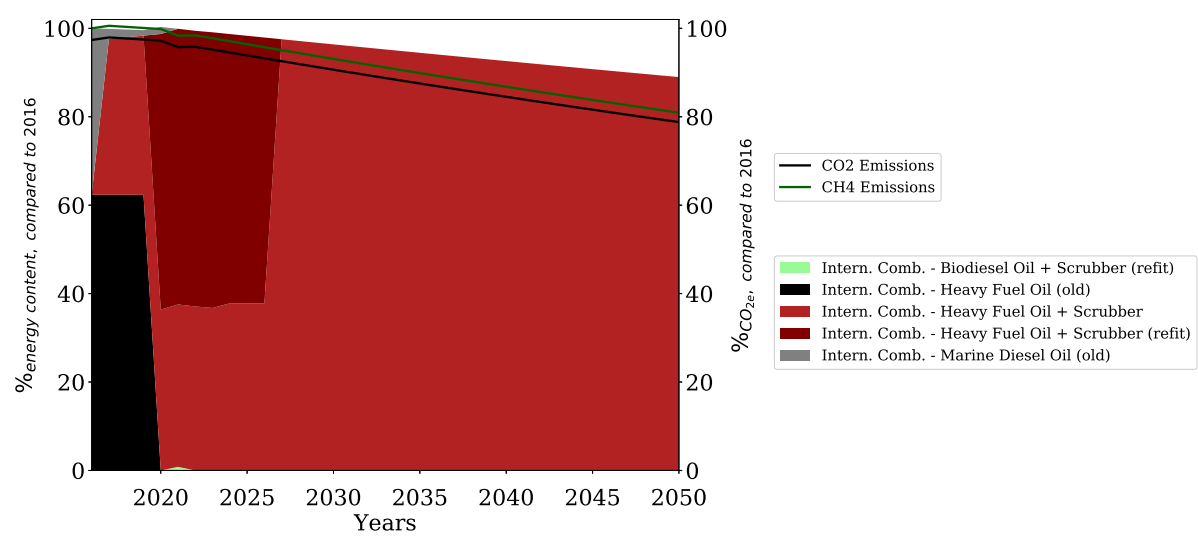

Figure C.9: Fuel consumption (y-axis left) and cumulative emissions (y-axis right) in the business-as-usual scenario without carbon restrictions. 


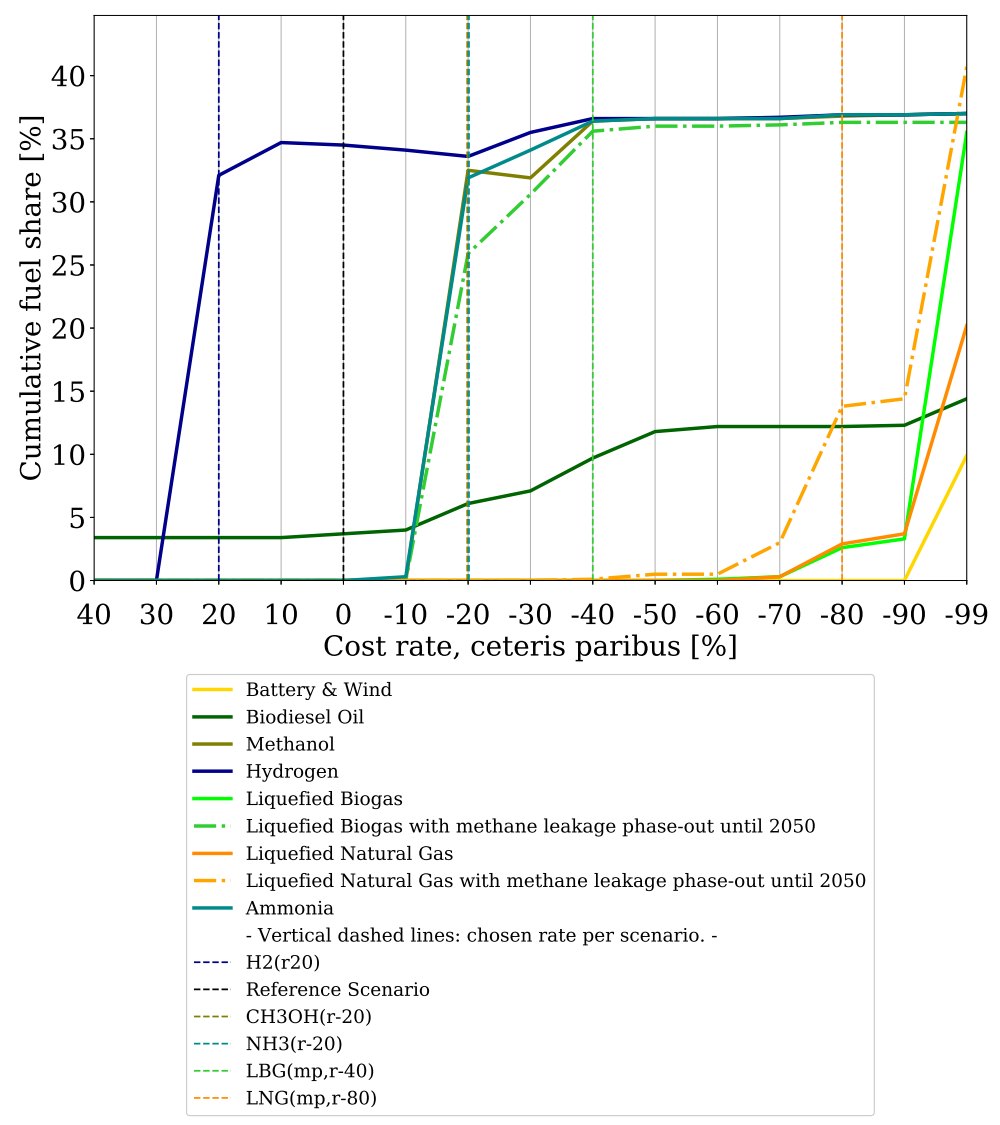

Figure C.10: Total fuel shares from 2016-2050 (y-axis) in relation to different cost range changes (x-axis) compared to the reference case.

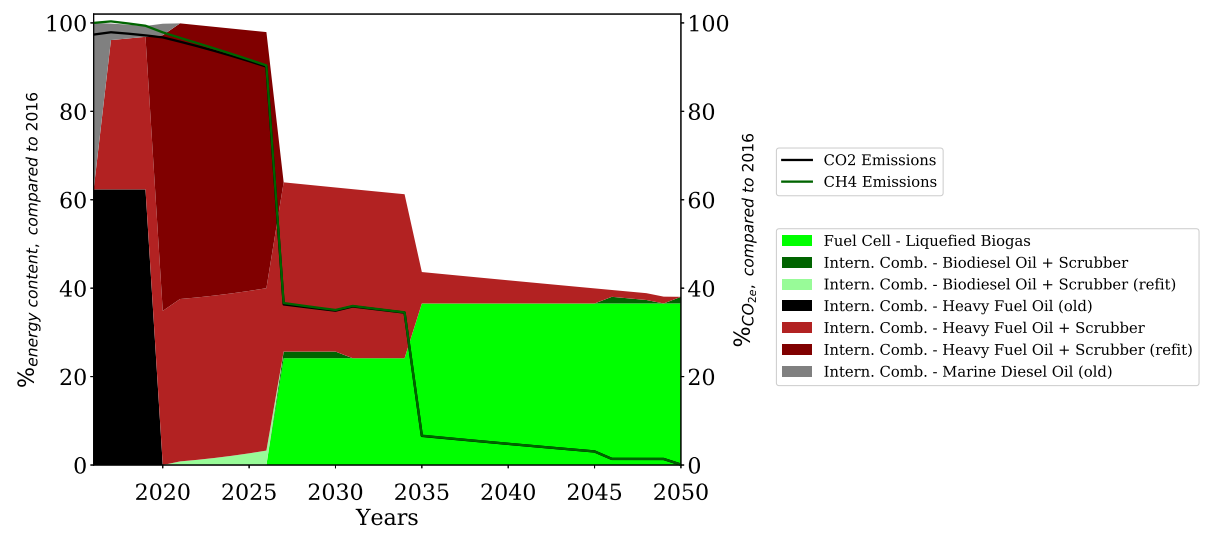

Figure C.11: Fuel consumption (y-axis left) and cumulative emissions (y-axis right) in the bio-methane scenario ( $\mathrm{LBG}(\mathrm{mp}), \mathrm{r}-40)$ and assuming methane leakage phase-out. 